\title{
Mobilization Initiatives for Enhancing Secondary School Students' Enrolment into Vocational and Technical Education Program of Universities for Self Reliance in South East, Nigeria
}

\author{
Isiwu Edward Chukwuka, Nwakpadolu Glory Nma \\ Department of Agricultural/Home Economics Education Michael Okpara University of Agriculture, Umudike, \\ Nigeria \\ Email: Edisiwu50@yahoo.com, geenuelsnigeria@hotmail.com
}

Received 13 June 2015; accepted 6 July 2015; published 9 July 2015

Copyright (C) 2015 by authors and Scientific Research Publishing Inc.

This work is licensed under the Creative Commons Attribution International License (CC BY).

http://creativecommons.org/licenses/by/4.0/

(c) (i) Open Access

\begin{abstract}
This study focused on identification of mobilization initiatives for enhancing student's enrolment into Vocational and Technical Education (VTE) programs in Nigerian Universities. Three research questions guided the study while three hypotheses were formulated and tested at 0.05 level of significance. The study was carried out in South East, Nigeria. Population for the study was 1340. Sample for the study was 753 obtained through proportionate (30\%) stratified random sampling technique. A 38 item questionnaire was developed and used to collect data. Data obtained were analyzed using mean and standard deviation to answer research questions while t-test statistic was used to test hypotheses at probability of 0.05 level. It was found out by the study that 38 mobilization initiatives could be used to enhance students' enrolment into Vocational and Technical Education Programs in Nigerian Universities. It was therefore recommended that the identified mobilization initiatives be implemented by relevant stakeholders to enhance secondary school students' enrollment into VTE programs in Nigerian Universities.
\end{abstract}

\section{Keywords}

Mobilization, Initiatives, Enrolment, Enhancing, Students, Education, Universities

How to cite this paper: Chukwuka, I.E. and Nma, N.G. (2015) Mobilization Initiatives for Enhancing Secondary School Students' Enrolment into Vocational and Technical Education Program of Universities for Self Reliance in South East, Nigeria. Agricultural Sciences, 6, 623-629. http://dx.doi.org/10.4236/as.2015.67061 


\section{Introduction}

Vocational and technical education is an aspect of learning which leads to the acquisition of practical and applied skills as well as basic scientific knowledge. It is a form of education designed to prepare students for employment in industry, agriculture and commerce after graduation. In the views of Okoro [1], vocational education aims at the development of human abilities in terms of knowledge, skills and understanding so efficiently in carrying on the activities in the vocational pursuits of his choice.

The aims and objectives of vocational and technical education, according to Olaitan [2], include to provide trained manpower in agriculture, technology, home management and business for commercial and economic development and give training and to impart the necessary skills to individual who shall be self-reliant economically. In the context of this study, vocational technical education is that form of education that leads to the acquisition of practical skills, which will enable students to be gainfully employed in a chosen occupation capable of making him/her self-reliant after graduation.

The challenges facing vocational and technical education program in Nigerian Universities in the views of Amoor [3] are the Federal Government's lukewarm attitudes towards Vocational and Technical Education programme. Okorie [4] also stated that insufficient funding by the government was a realistic and practical factor inhibiting the implementation of vocational and technical education programme in Nigeria. The author further said that priority of the Federal Government of Nigerian in education sector was holistically on science education. In the view of Waliki and Usman [5], the society had a negative perception towards Vocational and Technical Education in Nigeria. The author said that the society did not accord respect or recognition to the graduates of Vocational and Technical Education as they had the impression that this type of education was meant for the unintelligent and under-achievers. Most parents, according to Amoor [3], do not encourage or guide their wards to take a course in Vocational and Technical Education programme in Nigerian universities, because the society does not place any significant value or dignity on the programme. According to the author, this subsequently affects the enrolment of candidates into vocational and technical education programme in Nigerian universities.

It was observed by the researchers that most students seeking entry into universities in the South East, Nigeria preferred to study general management, physical sciences, medicine, engineering and other professional courses to vocational and technical education courses like agricultural education, home economics, business education etc, where they believed that they could easily secure white collar jobs. In an interactive session with some of the students in Government College Umuahia and Ibeku High school both in Abia State, it was revealed that many students did not have the interest to opt for vocational education courses in universities because they felt that vocational education programs were for the academically less endowed and the never did wells. A further investigation was made by the researchers during a conference held by the Science Teachers Association of Nigeria (STAN) in Enugu State (the capital city of the old Eastern state of Nigeria) in August 2013, where science teachers gathered for academic discussions and revealed that many parents wanted their children and wards to study either physical sciences, law, engineering and medical sciences with low emphasis on vocational education courses. In a communique presented at the conference, it was recommended that efforts should be made by parents and teachers in Nigeria to ensure that students at secondary schools level should be mobilized while in training towards embracing vocational courses they would be trained on skills and competencies that would make them self-reliant after graduation as a means of combating unemployment.

Mobilization in this context involves creating awareness in students about vocational and technical education programs, stimulating their interest towards enrolling into vocational courses in universities and helping them to maintain a quality standard of their choice vocation for self-reliance. In the opinion of Okorie [4], mobilizing and sustaining students to learn can be achieved by involving the teachers of vocational education and the government at all levels to bear the responsibility of teaching and disseminating information in schools and in equipping institutions with required facilities for effective learning. Mobilization of the students in the view of Clouse [6] will further be enhanced by putting in place well thought initiatives that can arouse the interest of the students. This initiative could be in the form of statements or guideline capable of stimulating and sustaining the interest of students towards identifying with programs on vocational and technical education in Nigerian universities. The purpose of this study therefore is to determine mobilization initiatives for enhancing students' enrolment into vocational technical education programmes in Nigerian universities for self-reliance. Specifically, this study seeks to determine the:

1) mobilization initiatives as it pertains to creating awareness and sustaining students' interest; 
2) levels of decision making and clarification of issues;

3) motivational requirements to students for choice of vocational education programmes in Nigeria.

\section{Method}

Three research questions guided the study and three hypotheses were formulated and tested at 0.05 level of significance. Survey research design was adopted for the study. Survey research design in the opinion of Nworgu [7] is a design in which group of people or items are studied by collecting and analysis data from a few people or items considered to be representative of the entire group. The study was carried out in South East Nigeria. The study population comprised 1340 senior secondary school students and 253 secondary school teachers in South East, Nigeria.

A 38 item questionnaire on mobilization initiatives in creating awareness and interest, decision making and clarification, and motivational requirements for Students' enrolment for effective VTE programmes was developed. The instrument had a four point response scale of Strongly Agree (SA), Agree (A), Disagree (D) Strongly Disagree (SD) with corresponding values of 4, 3, 2 and 1 respectively. The instrument was face validated by three experts. One from department of Guidance and Counselling from Michael Okpara University of Agriculture, Umudike in Abia State and two from department of Vocational Teachers Education from University of Nigeria Nsukka. The validators' comments helped in improving the questionnaire. Split half technique and Pearson Product Moment correlation method were used to determine the stability of the questionnaire which yielded a coefficient of 0.84 . Seven hundred and fifty three (753) copies of the questionnaire were administered on the respondents comprising teachers in Nigerian Secondary schools and students in Abia State through the help of 12 trained research assistants. 625 copies of the questionnaire were retrieved. The mean and standard deviation were used to answer the research questions. In taking decision on the value of the mean, arithmetic mean of the response options of 4, 3,2, and 1 was calculated and the result was 2.50. This was used as cut-off point. Any item with a mean value of 2.50 or above was regarded as an item agreed upon by the respondents as mobilization initiatives while any item below 2.50 was regarded as an item which the respondents disagreed with. Standard deviation was used to determine the closeness of the opinion of the respondents to the mean and one another. Any item with a standard deviation less than 1.96 (95\% confidence limit) indicated that the respondents were close to the mean and one another in their responses. The t-test statistic was used to test the null hypothesis. The null hypothesis was upheld for any item whose t-cal is lower than t-table value (critical value) while any item whose $t$-cal is greater than the t-table value (critical value) was rejected at probability of 0.05 .

\section{Result}

Results for this study were obtained from the research questions answered and hypotheses tested through data collected and analyzed.

Research question 1: What are the mobilization initiatives that could be used to create awareness and interest among students on enhancing students' enrolment into Vocational and Technical Education programme in Nigerian Universities?

Hypothesis 1: There is no significant difference in the mean ratings of the responses of senior secondary school students and teachers on mobilization initiatives that could be used to create awareness and interest among students on enhancing their enrolment into Vocational and Technical Education in Nigerian Universities.

The data for answering research question 1 and testing the hypothesis are presented in Table 1.

Data in Table 1 revealed that all the 16 items had their means ranged from 2.77 to 3.94. This showed that the means were above the cut-off point of 2.50 which indicated that all the 16 items were agreed upon as mobilization initiatives that could be used to create awareness and interest among students on enhancing their enrolment into VTE in Nigerian Universities. The table also revealed that all the 16 items had their standard deviation ranged from 0.17 to 0.28 which indicated that the respondents were not too far from the mean and were close to one another in their responses. The table also showed that all the 16 items had their t-cal lower than the critical value of 1.96 at probability of 0.05 level of significance and 230 degrees of freedom. This showed that there is no significant difference in the mean ratings of the responses of the two groups of respondents on mobilization initiatives that could be used to create awareness and interest among students in enrolling into VTE programme of universities.

Research question 2: What are the mobilization initiatives that could be used to help students make decision 
Table 1. Mean ratings and t-test analysis of the responses of senior secondary school students and teachers on mobilization initiatives that could be used to create awareness and interest among students on enhancing students' enrolment into Vocational and Technical education in Nigerian Universities $\mathrm{N}=625$.

\begin{tabular}{|c|c|c|c|c|c|c|c|c|c|}
\hline $\mathbf{S} / \mathbf{N}$ & Item Statement & $\bar{X}$ & SD & $\overline{X e}$ & $\overline{X t}$ & $\begin{array}{c}\text { S2 } \\
1\end{array}$ & $\begin{array}{c}\text { S2 } \\
\text { 2 }\end{array}$ & t-cal & Remarks \\
\hline 1 & $\begin{array}{l}\text { Organize regular vocational } \\
\text { activities targeting youth and the } \\
\text { communities }\end{array}$ & 3.84 & 0.26 & 2.71 & 2.84 & 0.78 & 0.52 & 1.25 & Agreed NS \\
\hline 2 & $\begin{array}{l}\text { Document success stories of } \\
\text { persons that excelled through voc. } \\
\text { Training skills }\end{array}$ & 3.81 & 0.28 & 2.94 & 2.98 & 0.81 & 0.68 & 1.27 & Agreed NS \\
\hline 3 & $\begin{array}{l}\text { Provide demonstration stalls at } \\
\text { schools/festivals }\end{array}$ & 2.94 & 0.24 & 2.88 & 2.96 & 0.71 & 0.65 & 1.28 & Agreed NS \\
\hline 4 & $\begin{array}{l}\text { Organise face to face } \\
\text { communication }\end{array}$ & 3.21 & 0.19 & 3.34 & 3.18 & 0.41 & 0.55 & 1.30 & Agreed Ns \\
\hline 5 & $\begin{array}{l}\text { Publish newsletters } \\
\text { periodically on vocational } \\
\text { education }\end{array}$ & 3.28 & 0.23 & 3.35 & 2.96 & 0.38 & 0.62 & 0.62 & Agreed NS \\
\hline 6 & $\begin{array}{l}\text { Use television to broadcast } \\
\text { documentaries on vocational } \\
\text { success }\end{array}$ & 2.93 & 0.17 & 3.12 & 2.87 & 0.66 & 0.72 & 1.83 & Agreed Ns \\
\hline 7 & $\begin{array}{l}\text { Employ trained career counsellors } \\
\text { to schools to help exploit students } \\
\text { career paths }\end{array}$ & 2.77 & 0.19 & 2.88 & 0.72 & 0.52 & 0.63 & 1.91 & Agreed Ns \\
\hline 8 & $\begin{array}{l}\text { Organise regular training to } \\
\text { sensitize youths on TVET }\end{array}$ & 3.10 & 0.26 & 3.21 & 2.93 & 0.68 & 0.61 & 0.64 & Agreed Ns \\
\hline 9 & $\begin{array}{l}\text { Publish Governments } \\
\text { accomplishment reports on } \\
\text { vocational education }\end{array}$ & 3.29 & 0.20 & 3.33 & 3.30 & 0.45 & 0.33 & 1.56 & Agreed Ns \\
\hline 10 & $\begin{array}{l}\text { Use SMS broadcasts and } \\
\text { e-mails sent by stakeholders }\end{array}$ & 3.15 & 0.28 & 3.26 & 3.19 & 0.53 & 0.30 & 1.57 & Agreed Ns \\
\hline 11 & $\begin{array}{l}\text { Publish TVET survey reports } \\
\text { by experts }\end{array}$ & 2.90 & 0.18 & 3.18 & 2.84 & 0.58 & 0.51 & 1.30 & Agreed Ns \\
\hline 12 & $\begin{array}{l}\text { Use social networks like tweeter, } \\
\text { facebook, whatsapp etc to reach } \\
\text { out to the youth }\end{array}$ & 3.23 & 0.25 & 3.41 & 3.20 & 0.48 & 0.57 & 0.65 & Agreed Ns \\
\hline 13 & $\begin{array}{l}\text { Use singers and actresses to } \\
\text { feature TVET programs on TVs } \\
\text { and radios (infomercials) }\end{array}$ & 3.28 & 0.24 & 3.21 & 3.10 & 0.32 & 0.78 & 0.58 & Agreed Ns \\
\hline 14 & $\begin{array}{l}\text { Organise periodic press releases } \\
\text { on TVET programs }\end{array}$ & 3.41 & 0.28 & 2.98 & 3.21 & 0.35 & 0.58 & 0.54 & Agreed Ns \\
\hline 15 & $\begin{array}{l}\text { Display streamers, banners and } \\
\text { bill boards in strategic positions } \\
\text { inviting the public on TVET } \\
\text { programs }\end{array}$ & 3.88 & 0.24 & 2.73 & 3.28 & 0.34 & 0.56 & 0.55 & Agreed Ns \\
\hline 16 & $\begin{array}{l}\text { Organise exhibits, fairs, skills } \\
\text { competitions and foras on TVET } \\
\text { periodically }\end{array}$ & 3.74 & 0.19 & 2.94 & 2.87 & 0.28 & 0.64 & 0.60 & Agreed Ns \\
\hline
\end{tabular}

and clarify issues?

Hypothesis 2: There is no significant difference in mean ratings of the responses of senior secondary school students and teachers on mobilization initiatives that could be used to help students make decision and clarify issues on enrolment into Vocational and Technical education in Nigerian Universities.

The data for answering research question 2 and testing the hypothesis are presented in Table 2.

Data in Table 2 revealed that all the 9 items had their means ranged from 2.85 to 3.31 . This showed that the means were above the cut off point of 2.50 which indicated that all the 9 items were agreed upon as mobilization initiatives that could be used to help students make decisions and clarify issues on enrolment into Vocational 
Table 2. Mean ratings and t-test analysis of the responses of secondary school students and teachers on mobilization initiatives that could be used to help pupils make decisions and clarify issues on enrolment into Vocational and Technical Education in Nigerian Universities. $\mathrm{N}=625$.

\begin{tabular}{|c|c|c|c|c|c|c|c|c|c|}
\hline $\mathbf{S} / \mathbf{N}$ & Item Statement & $\bar{X}$ & SD & $\overline{X e}$ & $\overline{X t}$ & $\begin{array}{c}\text { S2 } \\
1\end{array}$ & $\begin{array}{c}\text { S2 } \\
2\end{array}$ & t-cal & Remarks \\
\hline 1 & $\begin{array}{l}\text { Explain to students the benefits } \\
\text { associated to choice of } \\
\text { Vocational education courses }\end{array}$ & 2.85 & 0.31 & 3.07 & 2.88 & 0.49 & 0.68 & 0.76 & Agreed Ns \\
\hline 2 & $\begin{array}{l}\text { Encourage students to take part } \\
\text { in vocational skills awareness } \\
\text { programs in their communities }\end{array}$ & 2.93 & 0.22 & 2.98 & 2.92 & 0.50 & 0.53 & 1.50 & Agreed Ns \\
\hline 3 & $\begin{array}{l}\text { Explain to the students lessons } \\
\text { to be learnt from vocational } \\
\text { entrepreneurs }\end{array}$ & 3.19 & 0.24 & 3.18 & 2.96 & 0.45 & 0.57 & 0.72 & Agreed Ns \\
\hline 4 & $\begin{array}{l}\text { Explain to students the dangers } \\
\text { inherent in joblessness after } \\
\text { graduation }\end{array}$ & 2.86 & 0.21 & 3.08 & 2.84 & 0.47 & 0.71 & 0.77 & Agreed Ns \\
\hline 5 & $\begin{array}{l}\text { Identify laudable vocations } \\
\text { with the students within their } \\
\text { locality }\end{array}$ & 3.31 & 0.29 & 3.39 & 3.21 & 0.44 & 0.43 & 1.82 & Agreed Ns \\
\hline 6 & $\begin{array}{l}\text { Encourage students to identify } \\
\text { their latent potentials }\end{array}$ & 2.82 & 0.17 & 2.78 & 2.83 & 0.56 & 0.46 & -0.82 & Agreed Ns \\
\hline 7 & $\begin{array}{l}\text { Encourage students to visit } \\
\text { vocational skills/technical } \\
\text { centres }\end{array}$ & 2.96 & 0.27 & 3.13 & 2.82 & 0.42 & 0.49 & 1.92 & Agreed Ns \\
\hline 8 & $\begin{array}{l}\text { Encourage students to gather } \\
\text { enough information about the } \\
\text { benefits of VTE }\end{array}$ & 3.25 & 0.18 & 3.28 & 2.92 & 0.48 & 0.57 & 0.64 & Agreed Ns \\
\hline 9 & $\begin{array}{l}\text { Guide students towards } \\
\text { identifying their career paths }\end{array}$ & 3.16 & 0.26 & 3.22 & 2.86 & 0.44 & 0.48 & 0.73 & Agreed Ns \\
\hline
\end{tabular}

and technical education in Nigerian Universities.. The table also revealed that all the 9 items had their standard deviation ranged from 0.17 to 0.31 which indicated that the respondents were not too far from the mean and were close to one another in their responses. The table also showed that all the 9 items had their $\mathrm{t}$-cal lower than the critical value of 1.96 at probability of 0.05 level of significance and 230 degrees of freedom. This showed that there is no significant difference in the mean ratings of the responses of the two groups of respondents on mobilization initiatives that could be used to help students make decisions and clarify issues on enrolment into VTE programme of universities.

Research questions 3: What are the motivational factors that could be employed to promote quality and attraction to students in order to enhance their enrolment into Vocational and Technical Education in Nigerian Universities?

Hypothesis 3: There is no significant difference in the mean ratings of the responses of secondary school students and teachers on motivational initiatives that could be used to promote students enrolment into Vocational Technical Education in Nigerian Universities.

The data for answering research question 3 and testing the hypothesis are presented in Table 3.

\section{Discussion of Result}

The result of the study in table one revealed that 13 items were identified as mobilization initiatives that could be used to motivate students to enrol into VTE program in Nigerian universities. The result of the study in table 2 revealed that 13 items were identified as mobilization initiatives that could be used to motivate students towards enrolment into VTE programs. Result of the study in Table 3 showed that 13 items were identified as mobilization initiatives that could be used to motivate students' and enhance their enrolment into VTE programs in Nigerian Universities. 
Table 3. Mean ratings and t-test analysis of the responses of senior secondary school students and teachers on mobilization initiatives that could be used to motivate students and enhance their enrolment into Vocational and Technical Education in Nigerian Universities.

\begin{tabular}{|c|c|c|c|c|c|c|c|c|c|}
\hline $\mathbf{S} / \mathbf{N}$ & Item Statement & $\bar{X}$ & SD & $\overline{X e}$ & $\overline{X t}$ & $\begin{array}{c}\text { S2 } \\
1\end{array}$ & $\begin{array}{c}\text { S2 } \\
2\end{array}$ & t-cal & Remarks \\
\hline 1 & $\begin{array}{l}\text { Consider students in planning } \\
\text { for success in VTE program } \\
\text { implementation }\end{array}$ & 3.21 & 0.26 & 3.41 & 3.36 & 0.59 & 0.62 & 1.30 & Agreed Ns \\
\hline 2 & $\begin{array}{l}\text { Locate vocational skill centres } \\
\text { and their accessibility in the } \\
\text { community }\end{array}$ & 3.31 & 0.19 & 3.36 & 3.29 & 0.71 & 0.58 & 1.16 & Agreed Ns \\
\hline 3 & $\begin{array}{l}\text { Organise competition with } \\
\text { reward among community } \\
\text { students on vocational skills }\end{array}$ & 2.93 & 0.23 & 3.19 & 2.86 & 0.45 & 0.61 & 1.41 & Agreed Ns \\
\hline 4 & $\begin{array}{l}\text { Reward students effort in } \\
\text { production skills and } \\
\text { demonstration accordingly }\end{array}$ & 3.06 & 0.17 & 2.98 & 2.95 & 0.55 & 0.64 & 1.84 & Agreed Ns \\
\hline 5 & $\begin{array}{l}\text { Encourage students to visit } \\
\text { vocational schools/centres for } \\
\text { observation and experience } \\
\text { sharing }\end{array}$ & 2.93 & 0.24 & 3.09 & 2.84 & 0.43 & 0.52 & 1.17 & Agreed Ns \\
\hline 6 & $\begin{array}{l}\text { Lead students on exhibition } \\
\text { events }\end{array}$ & 3.28 & 0.28 & 3.34 & 3.31 & 0.58 & 0.52 & 0.65 & Agreed Ns \\
\hline 7 & $\begin{array}{l}\text { Provide clear directions to } \\
\text { Vocational educators on VTE } \\
\text { program }\end{array}$ & 3.37 & 0.21 & 3.21 & 3.33 & 0.56 & 0.56 & -0.87 & Agreed Ns \\
\hline 8 & $\begin{array}{l}\text { Provide supportive } \\
\text { environments that include } \\
\text { incentives }\end{array}$ & 2.82 & 0.26 & 2.90 & 3.10 & 0.73 & 0.62 & -1.24 & Agreed Ns \\
\hline 9 & $\begin{array}{l}\text { Make provision for adequate } \\
\text { resources and funding to } \\
\text { facilitate VTE program }\end{array}$ & 3.35 & 0.28 & 3.11 & 3.28 & 0.54 & 0.63 & -1.28 & Agreed Ns \\
\hline 10 & $\begin{array}{l}\text { Re-assess pre- and in-service } \\
\text { teacher education programs }\end{array}$ & 3.28 & 0.24 & 3.19 & 3.11 & 0.57 & 0.61 & 0.65 & Agreed Ns \\
\hline 11 & $\begin{array}{l}\text { Eliminate unnecessary } \\
\text { bureaucracy regarding VTE } \\
\text { implementation activities }\end{array}$ & 3.32 & 0.26 & 3.21 & 3.09 & 0.58 & 0.63 & 0.68 & Agreed Ns \\
\hline 12 & $\begin{array}{l}\text { Send teachers to in-service and } \\
\text { professional development } \\
\text { training }\end{array}$ & 3.30 & 0.28 & 3.29 & 3.02 & 0.56 & 0.68 & 0.53 & Agreed NS \\
\hline 13 & $\begin{array}{l}\text { Award scholarships to } \\
\text { outstanding students in } \\
\text { vocational education }\end{array}$ & 3.35 & 0.27 & 3.24 & 3.18 & 0.59 & 0.62 & 0.54 & Agreed NS \\
\hline
\end{tabular}

\section{Findings}

The findings of this study is in agreement with the finding of Olaitan, Alawa and Uzuegbunam [8] [9] in a study on "mobilization initiatives for enhancing secondary school students' participation in soil erosion management in schools in Cross River State, Nigeria" where it was found out that 36 mobilization initiatives could be used to enhance secondary school students' participation in soil erosion prevention and control.

The findings of this study is in conformity with the finding of Abelega [10] in a study on "mobilization initiatives for enhancing farmers' participation in soil erosion management in agriculture in Anambra State, Nigeria" where it was found out that farmers could be mobilized for participation in soil erosion management through initiatives on creation of awareness, interest, decision making, clarification, adoption and satisfaction.

The hypothesis tested by the study revealed that there was no significant difference in the opinions of the two groups of respondents on mobilization initiatives that could be used to enhance pupils' participation in soil erosion management. The implication of these findings is that the professional inclination or experiences of the respondents did not significantly influence their responses to manifest into great differences in opinions. 


\section{Conclusion}

In the area of study, it was observed by the researchers that secondary school students and some parents did not have the interest in studying vocational and technical education at university level. The researchers identified some problems that militated against low students' enrolment in vocational and technical education programme in University in South East, Nigeria. Some of such constraints include lack of societal respect for vocational education, the negative notion that vocational education programs are for the academically less endowed and the never do wells, the time consuming nature of the programs, and ignorance of career opportunities in VTE programs among others. This should be an assumed responsibility of every Nigerian citizen given the importance of vocational education to economic development. This study was conducted to identify mobilization initiatives that could be used to enhance secondary school students' enrolment in VTE programs in Nigerian Universities. It was found out by the study that 38 mobilization initiatives could be used to enhance school students' enrolment in VTE programs in Universities. It was therefore recommended that the identified mobilization initiatives be implemented by relevant stakeholders including the government to enhance secondary school students' enrolment in vocational and technical programs in Nigerian Universities.

\section{References}

[1] Okoro, O.M. (1993). Principles and Methods in Vocational and Technical Education. Varsity Industrial Press, Onitsha.

[2] Olaitan, S.O. (2003) Understanding Curriculum. Ndudim Printing and Publishing Company, Nsukka.

[3] Amoor, I.S. (2009) Policy Initiatives for Improving the Administration of Technical Teacher Training Programme in Nigeria. Unpublished Ph.D. Thesis, Department of Vocational Teacher Education, University of Nigeria, Nsukka.

[4] Okorie, J.U. (2001) Vocational Industrial Education. League of Researchers' in Nigeria, Bauchi.

[5] Waliki, L.M. and Usman, M. (2009) Achieving the Millennium Development Goals-MDGs by 2015 through Effective Teaching of Agricultural Science of Nigeria. The Voice of Teachers, 1, 32-36.

[6] Clouse, P.C. (1985) The Agricultural Teacher: The Key in Programme Improvement. The Agricultural Education Magazine, 57, 21-23.

[7] Nworgu, B.G. (2006) Educational Research: Basic Issues and Methodology. University Trust Publishers, Nsukka.

[8] Okeke, B.S. (2004) Teaching in Nigeria: A Case for professionalization. Varsity Industrial Press, Onitsha.

[9] Olaitan, S.O., Alawa, D.A. and Uzuegbunam, C.O. (2009) Mobilization Initiatives for Enhancing Secondary School Students' Participation in Soil Erosion Management in Schools in Cross River State, Nigeria. Nigerian Vocational Journal, 13, 108-119.

[10] Abelega, M.A. (2009) Work Oriented Education in Agriculture. A Journal of Teacher Education, 7, 109-115. 